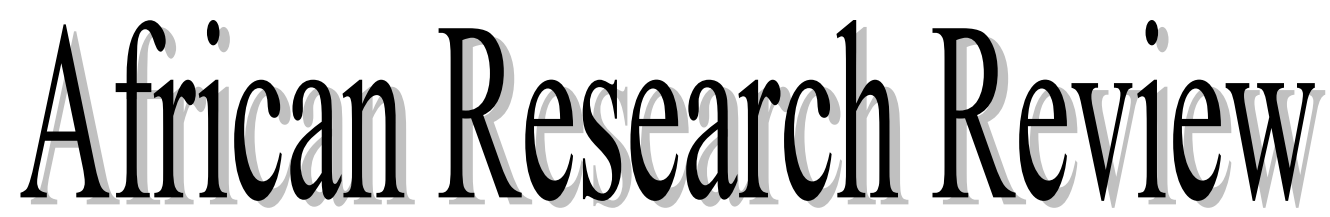

AN INTERNATIONAL MULTI-DISCIPLINARY JOURNAL,

\author{
BAHIR DAR, ETHIOPIA
}

AFRREV VOL. 11 (4), SERIAL NO. 48, SEPTEMBER, 2017:192-207

ISSN 1994-9057 (Print)

ISSN 2070-0083 (Online)

DOI : http://dx.doi.org/10.4314/afrrev.v11i4.16

\title{
Myths as Contextual Logic for Social Control: The Igbo Example
}

\author{
Ihejirika, Cardinal I. C. \\ Department of Philosophy \\ University of Port Harcourt \\ cardinalihejirika@gmail.com \\ $+2348028279646$
}

$\&$

\section{Edodi, Sampson Obok \\ Department of Philosophy \\ University of Port Harcourt \\ edodi_sampson@yahoo.com \\ $+2348163870849$}

\begin{abstract}
This work argues for the evaluation of myths within the context of their role as a means of social control through the transmission of cherished cultural values and norms, using Igbo mythology as a case study. It argues that the epistemic credentials of myths are largely determined by their historical and cultural contexts; hence, myths defy universal logic and rationalism. It is thus inappropriate, misleading and a mismatch of categories to subject myths to modern Western criteriology, which regards myth as a logically bankrupt, pre-scientific and anachronistic mode of thought. This study contends that such pejorative categorization derives substantially from enculturation, which is the process by which the dominant Western culture completely undermines non-Western belief systems. Our study also reveals that Igbo mythology richly embodies practical rules that guide social living. From three instantiations made in this paper, we observe that myths simply prefer a different logic, which is less stringent and argumentative than those of both science and Western epistemology. Its logic recognizes diversity of cultures and "polysemy" of linguistic expressions. This study
\end{abstract}

Copyright (C) International Association of African Researchers and Reviewers, 2006-2017: 
utilizes the expository and comparative methods of inquiry. It recommends an acculturation ideology, which integrates the best elements of sciento-cultural rationalities. This fusion, charts a path for society's growth, thereby fostering social control and protecting human personhood from the destructive backlashes of science and technology.

Key Words: Myths, Contextual Logic, Social Control, Acculturation, Igbo

\section{Introduction}

Social attachment, commitment, involvement, and beliefs are elements for social control which myths invoke into the heart and conscience of the members of societies that consider them relevant. These elements are contextually dependent yet, in the history of social evolution, science and religion are replete with diaries of mythological concepts. For example, myths have paved way among others for formation of civil and more rational societies, attainment of many scientific breakthroughs and religious expansions. The word, myth originates from the Greek word mythos which means "story" or "word". Thus, myth is "story wording'. Such stories have aided human social control systems at different epochs. Albert Camus" in "The Myth of Sisyphus (1943)" describes the inherent absurdity of human life, a profound meaninglessness that can be mitigated only by moral integrity and social solidarity. Several social solidarity movements for decades have been spurred by some mythological conceptions of certain individuals or communities. Myth therefore, has its contextual logic. Yves Bouchard has it that contextual logic, "originally developed by John Mc Carthy in the field of artificial intelligence aims at providing a solution to the problem of generality." (310-319). It resolves the problem of representing ordinary knowledge and its integration into inferential processes operating on knowledge bases. An inferential context or context of inference gives justification to knowledge claims in specific scenario thereby lending credence to justified true belief theory.

However, Edmund Gettier critiques the contextual logic of 'justified true belief'. His main thesis is that, justified true belief does not constitute sufficient condition for knowledge. Gettier reports that, "various attempts have been made in recent years to state necessary and sufficient conditions for someone's knowing of a given proportion" (306). He nevertheless, commits himself through the use of counter-examples and series of cases to proving that "justified True Belief theory" is not a sufficient condition for knowledge. In our opinion, justified true belief, validates myths as contextual logic. Thus, contextual logic is a rational mode of inference wherein specific contexts', justified true beliefs inferentially define mythical syntax and mythical semantics according to the specific situations of need of social controls.

The concept of social control is a conflict theory. It is a perspective of conflict resolution that assumes that "The idea of a society are the ideas of a ruling class". (Boundless 2016). Kimbal Young has social control as the use of coercion, force, restraint, suggestion or persuasion of one group over another or of a group over its members or of persons over others to enforce the prescribed rules of the game. Boundless however argues that "social control refers generally to societal and political mechanisms or processes that regulate individual and group behavior, leading to conformity and compliance to the rules of a given society, state, or social group" (www.bandless.condi/sociology/textbooks). It involves some concepts such as

Copyright $\odot$ International Association of African Researchers and Reviewers, 2006-2017: www. afrrevjo.net.

Indexed African Journals Online: www.ajol.info 
acceptable behaviors, formal social control, and indoctrination. Acceptable behaviors are those acts which conform to social norms. Formal social control instruments refer rightly to societal and political mechanisms or processes which regulate individual and group behavior thus leading to conformity and compliance to the rules of a particular society, state, or social group. It is undertaken by the state through legal action while indoctrination has to do with directives in the rudiments of belief systems.

This work therefore examines the roles myths as contextual logic, play in trimming human behavior to conform to approved social norms that hold true in Igbo society. We aimed at showcasing the significances of myths in character formation among the young in order to engender social control. We also attempted to clarify the right perspectives myths should be understood and how they can be fused with scientific rationality for a balanced societal growth and enhanced development.

\section{Elements of Social Control}

Our discussion on elements of social control leans on the submission of Travis Hirschi. Hirschi's sociological theory of social control has it that, "A person will engage in deliquent behavior when their "social bond" to society is weakened. This social bond comprises of four things: attachments, commitment, involvement, and beliefs" (Causes 68). Attachment includes mutual relationship between an individual and the society. Persons with good relationships with other members of the society are possibly, less likely, to violate societal norms. In other words, anyone who is closely knitted to family, friends, and community or institutions like the church would want to keep the bond because he would want to fulfill his obligations to the close ties (in the Platonic sense of maintaining justice) with the aim of avoiding harm to the relationship (with the Camus sense of having relationship worth keeping or life worth living without distressing it). On the other hand, "commitment refers to individuals investing time, energy and resources into conforming to social norms and expectations ...these are less likely to deviate from their commitment than those who are not so invested (Chriss 25).

Hirschi's concept of involvement has it that, the "Large amounts of structured time spent in socially approved activities reduces the time available for deviance." (72). For example, an individual who is engaged in a productive activity like employment would have less time for social unrest. Such activities bring self-fulfillment thereby giving more meaning to life and reducing suicide tendencies, and engenders contributions of individual's quota to societal development for the enhancement of social justice. However, another element of social control according to Hirschi is belief. This has to do with individual's level of belief in the validity of shared social values and norms. Those, who question or challenge the norms are more likely to deviate from them.

\section{A Contextual Logic: The Case of Myths}

Plato's idea of justice and Albert Camus' Myth of Sisyphus are two classical examples where myths serve as contextual logic for social control in any society. In the Republic, Plato couches a social issue in myth concerning the state, which is a classic example of how myth serve as contextual logic for social control. In his idea of social life, Plato holds that societies are invariably formed for a particular purpose. Individual human beings are not self-sufficient; no one working alone can acquire all the genuine necessities of life. For Plato, that separation of functions and specialization of labour are the keys to the establishment of a worthwhile society. He holds that, effective social

Copyright (C) International Association of African Researchers and Reviewers, 2006-2017: www.afrevjo.net.

Indexed African Journals Online: www.ajol.info 
life requires guardians of two distinct sorts: soldiers (guardian auxiliaries) and rulers (guardians proper). There must be both soldiers, whose function is to defend the state against external enemies and to enforce its laws, and rulers (philosophers), who resolve disagreements among citizens and make decisions and public policy. The guardians collectively, then are those individuals whose special craft is just the task of government itself. Whereas it belongs to the artisans to provide material things for sustenance of the guardian classes.

For to Plato, good social control is rooted in virtues obtainable in the state. Virtue is the ability to have mastery over the appetitive and spirited parts of the society. He considers the state as a natural institution and maintains that its origin is a reflection of people's economic needs. He posits that "a state comes into existence and that no individual is self-sufficing". We all have many needs, our many needs require many skills, and no one possesses all the skills needed to produce food, shelter, and clothing and as well as the various arts". (Plato 55). Hence for Plato, there must be a division of labour for "more things will be produced and the work more easily and better done. When every person is set free from all other occupations to do, at the right time, the one thing for which he is naturally fitted" (Plato 56-57). In other words, proper division of labour is a good element of good government. Thus, for Plato, a good state and government consists of harmony and natural cooperation among the three classes of people in the state, contentment with natural disposition of the three parts of the soul with each staying in their places and doing their special task and each maintaining it's expected virtue of temperance, courage, and wisdom. When these are achieved, Plato holds that we will have a good or just government as he stated and that just as justice is the general virtue of the moral person, so also, justice characterizes the good society. With this myth, which claims that these classes of people are differently made with gold, iron and admixture of clay and bronze. Plato is able to advance his theory of justice and societal organization advocating that each individual should be virtuous and contented with his/her class in order that there be social control in the state.

In The Myth of Sisyphus, Sisyphus is presented by Albert Camus as super smart but super evil too. Sisyphus does all kinds of bad stuffs like impregnating his niece in a plot to kill his brother. Some say he also kills guests and travelers, and even betrays the secrets of the gods. As punishment for his crimes, Zeus sends Thanatos the god of death, to chain Sisyphus down in Tartarus. Sisyphus outsmarts Thanatos, though, and leaves the death god chained instead (Shmoop 2008). When Sisyphus is eventually put back up in the underworld. He escapes again by convincing Persephone to let him go back and punish his wife for not giving him a proper burial (never mind the fact that he told his wife not to bury him). Eventually, Zeus steps in and gets Hermes to drag Sisyphus back down to the underworld for good. As punishment for his crimes, Sisyphus was constantly struggling with life's absurdity; its meaninglessness and the question of whether it is worth living.

According to the myth, Camus claims that the only important philosophical question is suicide, if we should continue to live or not. The rest is secondary because no one dies for scientific or philosophical arguments. Men usually abandon them when their lives are at risk. Yet, people do take their own lives because they judge them meaningless or sacrifice them for meaningful causes. This suggests that questions of meaning supersede all other scientific or philosophical questions. As Camus puts it, "I therefore

Copyright $\odot$ International Association of African Researchers and Reviewers, 2006-2017: www. afrrevjo.net.

Indexed African Journals Online: www.ajol.info 
conclude that the meaning of life is the most urgent of questions." (72) It could be recalled that, Camus' interest is what leads to suicide. For him, killing oneself is admitting that all the habits and efforts needed for living are not worth the trouble. As long as we accept reasons for life's meaning, we continue but as soon as we reject these reasons, we become alienated- we become strangers from the world. Shmoop asserts that it is this feeling of separation from the world which Camus, calls absurdity, that is the sensation that may lead to suicide.

In other words, once one settles within himself that life is not worth living anymore, the fellow is only a blink of an eye away from suicidal attempt. Nowhere is the essence of the human condition made clearer than in the Myth of Sisyphus. Condemned by the gods to roll a rock to the top of a mountain, whereupon its own weight makes it fall back down and again, Sisyphus got condemned to this perpetually futile labour. His crimes seem slight, yet, his preference for the natural world instead of the underworld incurred the wrath of the gods. "His scorn of the gods, his hatred of death, and his passion for life won him that unspeakable penalty in which the whole being is exerted towards accomplishing nothing". (79). He was condemned to everlasting torment and the accompanying despair of knowing that his labour was futile. The social control element in this myth is having a sense of life, worth living. Therefore, attachment, commitment, involvement, and beliefs are elements for social control which myths can invoke in the heart and conscience of the members of the society which holds them.

In any case, every human society has its own peculiar way or ways of interpreting their existential realities and shaping their environing situations. The effectiveness of these elements of rationality determine to a large extent, the measure different societies succeed or fail in the mastery of their environment, organization of their society, and leading of meaningful lives within their historical milieu.

Nevertheless, epistemic relativism enables societies to differently seek solutions to their problems in myriad ways. This is the reason an act of rationality in one community could as well qualify as folly in another community. However, all knowledge systems share the commonality of localness. Their differences may consist in the ways these elements are assembled either through social strategies and technical devices instrumentalized for the establishment of equivalences and connections between otherwise heterogeneous and incompatible components. Nick Turnbull in this connection, submits that "while some traditions move it through art, ceremony and ritual, science does it through forming disciplinary societies, building instruments, standardization techniques and writing articles" (67).

Relating the foregoing to myths, this study considers myth as a paradigmatic thinking that represents a logic employed as a tool of rationality in primordial times to give meaning to reality. This logic remains relevant in societies that still hold these myths. The reference to logic here is strictly in is interpretation as a type of reasoning undertaken and assessed according to specified principles of validity. In the fabrics of values and ethics of different peoples' culture, are discovered their charter of approved and disapproved behaviours that either validate or invalidate actions in that particular context. For instance, the early Ionians among whom are Thales, Anaximenes, Anaximander and Heraclitus, the materialist explanation of the ultimate stuff consisting all realities was a prevalent logic. The pre-Thales era of Homer and Hesiod featured the logic that ascribed almost all events in the mundane world to gods and their out

Copyright (C) International Association of African Researchers and Reviewers, 2006-2017: www. afrrevjo.net.

Indexed African Journals Online: www.ajol.info 
workings as couched in Myths. In the main, these ideas captured in the myths are direct expressions of their subject matter and not just merely symbolic as many erroneously believe. However, the derision associated with the term, myth as a category for delineating other people as primitive are glaringly found in Wilhem von Nestle's "Vom Mythos Zum Logos Concept" (Detienne13) and also prominent in G.S. Kirk's (1970) publication. Calame cited in Synnove des Bouvrie "The Definitions of Myth, Symbolic Phenomena in ancient culture" tells us that the Greeks, themselves lacked a term for what we identify as 'myth'. Rather, "all great exploits of ancestors, heroes, demigods of the past were comprehensively contained in a genre the Greeks called ta palaia, which means the ancient things or events" (14). Despite that, the Greek word Muthos does not refer to a distinct category of tales among the early Greeks but there were at least logical elements there-in that could be gleaned out as representing reality.

Myths are therefore not explanations done with the intent of satisfying a scientific interest. Instead, they belong to the class of narratives that resurrect a primeval reality. They are told to assuage deep religious thirst, moral cravings, social submissions, assertions and even practical requirements as in the case of social control. (Turnbull 67). Myth then belong to the logic that enhances, codifies and moralizes belief. It safeguards and enforces morality, vouches for the efficiency of ritual and embeddes within it, practical rules for man's guidance. It is not then an idle tale rather, a hardworked active force and a pragmatic embodiment of primitive faith and moral wisdom.

The dismissal of mythic consciousness and reasoning as a meaningless aberration in philosophical circle is a product of a Eurocentric enculturation ideology, which mercilessly annihilates indigenous ways of life (and considers all cultures other than those of the so called 'enlightened West' as primitive). Calame buttresses the foregoing observation by asserting that:

Myth is not an entity with only ontological existence but rather, a western category, which originated in the early days of anthropological thought during enlightenment. As a spatially and temporally marked tool of classification, the category "myth" is generated by the act of looking at the cultures of others from Eurocentric perspective. ... in other words, the question whether 'myth' is only a fiction of western or European culture... should be reformulated into a discussion about our justification (or moral right) to qualify an 'myth' what natives recognize as 'nature' (a short hand for metaphysical, historical, social, biological or whatever reality (Lincoln 76. Bourne.13).

Basically, myths are not concerned with details rather, they are visions of totality. A myth is essentially, a concrete intermediary between images (concrete and particular) and concepts (abstract and universal).

For the Igbo, myth has universality and rationality peculiar to it which is closer to music than language. Nevertheless, its logic is not less demanding than that of science. Indeed, says Levi-strauss, "man has always thought as well as he does today" (Anthropologies. 255). That a living evolution like myth does not always tow most obvious logical paths (established by European reality) should not be the grounds to deny the enriching influence and place of myths and mythologies in Igbo worldview. After all, the often-repeated statement that mythical consciousness is a pre-logical

Copyright $\odot$ International Association of African Researchers and Reviewers, 2006-2017: www.afrrevjo.net.

Indexed African Journals Online: www.ajol.info 
mode of thought arises from a unicoval conception of the term, logical. As Ruch and Anyanwu submits:

A statement is logical if it contains no contradiction. In this sense, even a fairy tale which tells of a toad being transformed into a ravishing prince at the kiss of a beautiful princess may be perfectly logical. In strict sense, ...logic implies some form of inductive or deductive reasoning process, whereby the mind passes from premises to conclusion. The reasoning process may be demonstrative, dialectical, rhetorical or literary. Myth, where it uses a deductive process at all and not merely intuition, concentrates mainly on the latter two forms, whereas science and classical philosophy prefer formal demonstrative logic (35).

The foregoing argument indicates that myths are not pre-logical. Instead, they are differently logical but could be argued to be pre-demonstrative or pre-scientific. This conception of myths persuaded Ruch and Anyanwu to affirm that Africans understand myth as a complex set of signs both verbal and gestural, which account for some of the most fundamental problems of life and existence hence, "a vaguely surmised eternal destiny and an explanation of the meaning of his existence, the natural and social milieu in which he lives" (35).

\section{Myths as Vehicles of Social Control: The Igbo Example}

Igbos are members of the Igbo tribe in Nigeria, a country west of Africa. They are a people occupying principally the south-eastern part of Nigeria. This tribe is not concentrated in one place as such hence, extends to some parts of Delta and Midwestern regions of Nigeria. Igboland today consists of Anambra, Enugu, Ebonyi, Abia, Imo and Eastern part of Delta and River States. They live within latitude $50^{\circ}-60^{\circ}$ north of the equator and longitude 6.1 to $8.5^{\circ}$ East (Ihejirika 12). With the land mass of about 6,000 square miles which is bounded in the West by Benin and Warri people, on the East by Ibibio people, South by the Ogonis and on the North by the Idomas. Apart from Enugu, Awgu and Nsukka, Igbo land is low lying. Their traditional form of government is basically republican whereas, their occupation is either farming or trading. The word Ibo is also used to indicate a language group or better put, a culture group. Its reference as a culture group is the sense it is employed in this work.

The dominant philosophy of the Igbo is pragmatism. The Igbo man therefore does not concern himself with distinctions and classifications. He considers these as tools of another mode of philosophizing namely, that of system builders and metaphye his immediate society and environment. Among other different ways of achieving social control within his closely knit traditional society (which includes the observance and enforcement of social norms, rules, laws and socio-economic and institutional structures), the Igbos still hold on to myths as one of the vehicles of enhancing social control. Myths, by this, therefore represent a paradigmatic thinking which constituted the tool of rationality during the mythical age and has left imprints in some cultures, where it exerts some influence as is the case with the Igbos.

Vehicles of social control in this paper are to the sum of different methods utilized by any society to influence human behaviour towards maintenance of order. Our understanding of social control takes its ideological learning on G.A Lundberg's definition, which conceives social control as a term "designating those social

Copyright (C) International Association of African Researchers and Reviewers, 2006-2017: www.afrevjo.net.

Indexed African Journals Online: www.ajol.info 
behaviours which influence individuals or groups of individuals toward conformity to established or desired norms (03). There is no gainsaying the fact that no society smoothly functions without a harmonized (agreed upon) social order. The absence of such order leads to chaos, confusion and anarchy.

From the field of sociology, we learn about two basic but different forms of social control namely, informal and formal types of social control. In informal social control systems, conformity to societal norms and values is emphasized and enforced by parents, guardians, caregivers and communities being families 'writ-large'. This is done so that a particular way of life, belief system or world view is entrenched as such society's unique approved norms and ways of socialization. On the other hand, formal type of social control has to do with external sanctions, which organized governments enforce in order to prevent chaos and crises in the society.

Of uppermost interest to our paper is the informal strand of social control enforceable by rewards or sanctions and through the employment of cultural and ideological tools, which hold true within a particular society's socio-cultural cum religious milieu. Myths (and their associated genres of folklores and stories) constitute our field of discourse and are considered by the Igbo as one of the contextual instruments of social control. Hence, myths in the Igbo enclave embodies "the peoples understanding of their environment, their geography, history, medicine, social organization and religious ideas" (Oji 08). Malinowski therefore calls the myth, "The pragmatic charter of primitive faith" (78). The Igbos therefore, people conceive the universe as an organic whole into which man fits like an organ into a living body. He becomes conscious of the world from within it, as part and parcel of it. This intuition of being is not turned into ontology. It is not an abstract discourse about being and its transcendental attributes. Rather, it is the expression in the form of concrete signs of a lived experience, the experience of a limited contingent and mortal being living in dangerous, alien and slightly chaotic world.

This refusal to break up a living whole leads him to adopt an attitude whereby rather than seeking salvation in the affirmation of his individual self, the Igbo myth maker emphasizes social harmony and unity with his fellow man, both living and dead. Myths in Igbo culture serves an etiological function. They tell us why man must work by the sweat of his brow; why women must bring forth children in pain and so on. By so doing, an early orientation of the young into the pragmatic ways of the Igbos is ensured to avoid laxity in later life. Emile Durkheim was therefore right when she observes that "the value of myths lies in its ability to validate tribal morality and social adaptation (African Traditional Religion 16). Myths go beyond validating functions for example, the human mind played an important role in the biblical Abrahamic and Arabian stories. The myths of creation recorded in Genesis chapters one and two inform us that every Jew has to rest on the seventh day because God rested on the seventh day after creation.

From the foregoing, we discover that rituals and beliefs which hold true in Igbo worldview, receive their authoritative, authentication and explanation in myths. Through myths, a belief generally held among the Igbo is expressed and modified. Myths therefore vouch for the efficacy of rituals and contain practical rules for the guidance of man, hence myth by its very nature, is a vital ingredient for civilization. They are not about the activities of super humans and gods in pre-logical times, they are not about how men perceive other men to have lived else, they would have at best

Copyright (C) International Association of African Researchers and Reviewers, 2006-2017: www.afrrevjo.net.

Indexed African Journals Online: www.ajol.info 
parochially qualify as invented tales. Rather, myths among the Igbos are about how man should live. They are prescriptive accounts of commendable values and ethics of the people, which when adopted and lived, make for harmonious and more secure life. Like parables, they do not demand scientific investigation in order to be proved or disproved but even if their didactic lessons are subjected to verification, they always hold true in real lived experience of the people. Just as hyperboles are exaggerated for the sake of emphasis, myths are amplified and this is done for both their cognitive ends and epistemic values. Igbo myths are lived realities lumped together by the Ibo myth maker in forms or genres of folklores, fairy tales, superstitious beliefs, bedtime lullabies and tales, traditional and cultural practices targeted towards orientating, integrating and encouraging of the young to live responsibly within their communal settings. Any other logic employed to adjudge the rationality of myths and the role they play in the Igbo enclave ends up in a gross misunderstanding of Igbo perspective on myths and subsequent misrepresentation of the people.

However, Encyclopedia of philosophy Vol. 12 outlines different types of myths paraded in mythic societies to include: "myth of origin, eschatogy, destruction, time and eternity, myth of providence and destiny; memory and forgetting, myths of high and celestial gods, founders of religions kings and ascetics, myths of culture, esoteriological myths, messianic and millesian myths" (779-802). With this at the back of our minds, we will now retell some Igbo myths in order to point out their significances and how their moral imports constitute the raw materials for social control within the Igbo enclave.

\section{Some Igbo Myths and Their Significances}

We have made a selection of three Igbo myths whose significances support our social control thesis. The chosen three are namely myths that tell us: "Why the Dog Pants, Why the Bush Baby Makes a Nest Every other Day and Why the Face of the Moon is not bright". These three myths are culled from Anyanwu Herbert's, Knowing the Way and the What: Anthology of Ideological Myths (2002). These myths variously fall under Culture/Heroic myths, Ideological / Ritual myths, Nature/ Totemic myths. There are yet two other strands of myths called Religion/Theogonic myths / Cosmogonic and Creation myth. All these myths are re-told in Africa but the latest two, will not form part of the instantiation list of our discussion.

\section{Why the Dog Pants}

This myth falls under the genre of culture or heroic myths. Though it could also pass for a creation myth but it is primarily the former. Culture or heroic myths contain stories about a god, an animal or a race hero, who gave priceless gift to humanity like fire, medicine or music. It is otherwise called heroic myths because it tells of great ancestors, who performed some very great deeds while alive.

This Igbo myth has it that when Chukwu or Chi-ukwu literally translated (the Creator God) created the world, He allowed man to explore and feed him back with reports of all he needed that were not hitherto available. Therefore, when the trees started dying off, man reported to "Chukwu", who in order to make the trees live, sent rain. This rain was accompanied by cold, which was previously unknown to man. Cold was so unbearable that man re-consulted Chukwu seeking for a solution. As much as Chukwu would not withdraw the rain, He decided to send fire, with which man could warm

Copyright $\odot$ International Association of African Researchers and Reviewers, 2006-2017: www. afrrevjo.net.

Indexed African Journals Online: www.ajol.info 
himself during cold condition. Chukwu therefore asked man to send a messenger who would bring fire to man. The dog was sent and was given a glowing charcoal and instructed by Chukwu on how to make it into a flame. As the dog raced back to man, she noticed that the charcoal was quenching and in order to keep it aglow, she started fanning it by panting. This singular act of the dog kept the charcoal aglow throughout the duration of the journey. Since then, the dog pants while running thinking that she is still carrying the burning charcoal.

The significance of this myth is that it shows God as the creational power behind existents (fire, rain, man etc.) It also depicts the dog as one of the most obedient useful and friendly domestic pets. This myth explains why the dog is always found in a village setting around firesides. It is believed that she is enjoying the dividends of her errands, which shows that every act of obedience has its attendant rewards. The mythical late introduction of fire also tallies with the historical discovery of fire by the early man.

\section{Why the Bush Baby Makes a Nest Every Other Day}

This myth is an ideological myth, which tells us why certain rites and customs began and persists, their importance in peoples' lives and the reasons they are cherished.

The bush baby is one of the weakest and smallest rodents. Consequent upon her weak nature, she does everything possible to stay away from humans. She has no strength to fight back when offended. She therefore runs away from any impending danger and keeps to herself. She equally wanted to inculcate her habits into her children. In order to protect them from external influence and danger, she always stays with them but as time progressed, their store of food diminished necessitating her leaving them and going in search for food. Hunger therefore forced her to leave her babies in the nest alone but prior to her leaving, she gave them specific instruction, to be very vigilant and to report their experiences to her when she finally gets back.

On her return, she was very happy that the children were all safe. Asked about what transpired in her absence, almost all her children responded that no intruder attacked them. However, the youngest among them pointing at a very small ant, told the mother that actually nothing big came but a small ant, which was still in the nest. On hearing this and seeing the little ant, the bush baby immediately relocated to a new nest telling the children that from the same route through which the small ant came, another thing big could equally come. Consequently, the bush baby makes a new nest immediately anything even as small as an ant enters her nest and this has led her to making a new nest every other day.

The significance of this myth lies in its moral ladeness. It teaches the importance of good home upbringing of the children and their early orientation towards values that make for social cohesion and safety hence, the mother bush baby taking up her parental responsibility, gave her children an early orientation of careful watchfulness that leads to safety. By relocating to avoid trouble, the notes of social harmony and peaceful coexistence are struck into the veins of upcoming generations and these constitute a strong foundation for social control. Vigilance as a social value and a good sense of responsibility are all qualities exemplified by the youngest of bush baby children in giving the mother, the much-needed feedback. We will now take a look at the third and last instantiation of how Igbo myths are employed for social control. Our third myth is namely:

Copyright $\odot$ International Association of African Researchers and Reviewers, 2006-2017: www.afrevjo.net.

Indexed African Journals Online: www.ajol.info 


\section{Why the Face of the Moon Is Not Bright}

This myth belongs to Nature myths. A nature myth discusses animals or plant species or elements and natural phenomena, which are often contextually held in special regard and personified. They are also called Totemic myths because their stories most times are built around facts of nature. There are stories of sun god, the moon with a deity, pools, seas, rivers and forests having their own deities or gods and these falls under nature myths.

To account for why the face of the moon is not bright as that of the sun or why the moon does not emit enough light like the sun, the Igbos tell this myth. In the time past, the sun and the moon were living together and in harmony. Both of them were shinning simultaneously and as such, there was neither day nor night. The moon was very boastful and was always threatening the sun, but the threats were ignored by the sun, who pleaded that it would be better for them to continue living harmoniously. As the threats became unbearable, the sun decided to challenge back and it was decided that the rucus will be settled with a fight. Whoever defeats the other in the physical combat chooses when to shine. On the day of the contest, the overconfident and boastful moon invited all his friends including the stars to witness how he would shamefully humiliate the sun but the expected never happened. During the contest, the sun, who was earlier considered the underdog, became so energetic and gave the boastful moon the beating of his life. To crown it all, the sun threw the moon into a very muddy water, which so coloured her face up till today. As agreed prior to the contest, the sun chose to shine in the day and the moon and his numerous friends had no choice than to operate at night. The sun also decided never to appear at night but the moon sometimes comes up even in the day to beg the sun for reconciliation. This account for why the face of the moon is not bright but muddy and why it at times appears in the day.

This myth leaves us with a lot of lessons that promote social control. Excessive boasting and selfishness leads to social crises and humiliation hence, the plight of the moon. Again, that the sun mutually tolerated the boastful moon depicts tolerance as a necessary tool for social cohesion. Besides, the fact that the sun returns the challenge to the moon shows that there is a limit to perseverance and when this limit is crossed, social destabilization or what we may call crises results. The resolution of the sun not to shine in the night even after defeating the moon in combat, shows that selfcomportment and discipline encourages societal peace and limits social upheavals and wars. The conciliatory act of the moon to appear sometimes in the days also indicates her new-found humility, which is also necessary for peaceful social living.

\section{Placing Myths Where They Belong}

A careful scrutiny of the myths discussed above indicate that they are all attempts to explain realities. The aim of the myth maker in these myths is undoubtedly to explain the world and man's place in it. The explanation is not to be by purely empirical or purely intellectual categories, and not even by the senses and the intellect combined, because neither alone nor combined can these two faculties encompass the dimensions of the world. As Ruch and Anyanwu opine:

The mythmaker does not, like Berkeley, see the world as a projection of his perceptual faculties, he does not like Descartes proclaim "Cogito, ergo sum" and even less "Cogito, ergo numdus est". He is undoubtedly not an idealist,

Copyright (C) International Association of African Researchers and Reviewers, 2006-2017: www.afrevjo.net.

Indexed African Journals Online: www.ajol.info 
reducing the world to the dimensions of his mental categories and of his speculations... neither is he an empiricist... He does not wish to sit in empirical and intellectual judgement over the world. Like a good lawyer, he maintains 'remo judex in propria causa' and since he does not admit a dichotomy between the self and the object, between the knower and the reality known, between the subject and the world, in the judging the world, he would be judging himself (107).

In the world of myths, there is no knowledge for its own sake. Myths aim to satisfy all dimensions of human existence in its concreteness. It is less concerned with knowing than with preaching a feeling of security in the present, a sense of correctedness with existence in the past and a permanent impact for the future. It works to ensure social harmony and peace, yet, all knowledge is for practical ends. Now since human acts are specified by their formal object (that is by what they are aimed to achieve) knowledge is given its prime function by its practical end hence, purely theoretical or purely abstract knowledge may then seem senseless. A.S Kagame therefore submits that "myths rest upon a kind of metaphysics, which differs substantially from that of western philosophy" (133) while western philosophy recognizes purely physical causality, mythical cultures are conceived that only beings endowed with intelligence can act for a purpose.

Myths do not follow the fragmenting activity of abstractive knowledge, its contact with the real is more immediate and involves the whole man and not only his intellect. The objectivity is the same as that of the scientific, but it is expressed in a different act of signs from those normally used by scientists. The truth is that myths re-integrate us with the totality and this is made possible through an operation of ontological recognition. Myth is to a large extent a value philosophy in a sacred sense. G. Gusdort explains that: "value is proportional to the dose of sacred energy which the relationship with supernatural confers to the human reality" (576). It is even more or less philosophy, in the classical and rationalistic sense of the term. It is more because it transcends mere doctrine and theory but evolves into a way or mode of life in the sense of a way of behaving determined by a previous but in the sense of intuitive, nonabstractive and untheorized experiences of being. For this reason, myth is less than rationalist philosophy since it refuses to reflect over itself and because it does not formulate its intuitions in abstract terms.

On the other hand, myths have the advantage of rationalist philosophy to the extent that its mode of communication is more accessible to the uneducated folks. Existentialism is quite aware of this hence, authors such as Satre and Marcel put many of their philosophical ideas in the allegorical and concrete language of plays and novels. The wisdom of myths can be shared by all though much of its creativity are left to the listener. Guisdorf therefore warns that; "One of the tragedies of western man (especially if he is not religious) is that he has lost contact with a living myth... then he is left without an intelligible and absorbable meaning of life" (228).

Howbeit, the universality expressed by myth as Ruch and Anyanwu tell us “....is not a synthesis made of elements produced by a prior man-made analysis, but an intuitive grasp of an unanalyzed whole" (39). Consequently, the retelling of African myths to the young help to form them for a later harmonious social life in the community. It instills in the minors fear of contravening social norms being mindful of their

Copyright $\odot$ International Association of African Researchers and Reviewers, 2006-2017: www.afrrevjo.net.

Indexed African Journals Online: www.ajol.info 
backlashes both from men and the gods and inculcates values that hold sway in their society in them. It must be recalled at this juncture that only value gives meaning to reality. An object which is "merely there" begins to exist when it begins to participate in that value which objects receive from their integration in the sacred reality, under the supreme source namely, God and as O'Connor warns: "it is not more rational to prefer manufacturing processes to gods unless you have a good evidence in your favour" (A Critical History. 03).

The fact that myths employ the supernatural in its explanatory assignments should not be the basis of rejecting its services. There are certainly some roles myths play which nothing else can replace in Igbo culture. The narrative functions of myth in this enclave is the treasure chest for transmission of culture. Myths therefore, contains practical rules for the guidance of man hence, no cultural tradition can exist without these mythological foundations. For instance, the mythified masquerade societies, which dot the Igbo society are seen as an institution that maintenans of social control. The masquerades are feared owing to the belief that they represent the spirit of archancestors and at times, the very souls of the living dead. Their acts are interpreted as acts of ancestral spirits hence, the awe associated with masquerade in Igbo culture and tradition. How these ancestors and the living dead transform symbolically into masquerades in itself is mythical. If these beliefs have meaning, value or justification, they must have arisen from human experiences and must be products of culture. By culture, what is meant is a "human response to experience as well as the beliefs and ideas which enable human beings to live meaningful lives" (African Philosophy 82). "It is in myths that the principle and paradigms for all human conducts must be sought and recovered" (Footmarks 50) Herman Bauman was therefore right in the observation that "the myth is the clear presentation of the outlook of people living in communities. It is their objective and permanent philosophy of life" (African Tradition Religion 08).

We discover from our foregoing discussion that a very systematic and critical philosophy would certainly affirm that mythology fails every test of 'western' critical objectivity and conceptual clarity. By presenting happening as though they are accurate representations of the past and by disallowing any retelling of myths with some modifications, detractors of myths are armed to accuse myths of hindering research due to their fixed and rigid nature. While such a philosopher would be correct to some extent in his/her judgement, it would also be discovered that he or she, at the end of the day, is examining the wrong candidate. Various reasons account for this latest affirmation. For instance, the mythic man does not want to know in the conceptual, critical sense, to which the classical philosophers are used to. He rather seeks a wisdom of life instead of a science of reality. But while myths lack discursive verification, it may not mean that it lacks all criteria. The very strength of its impact on man and social control proves that it must carry its proof within itself. The truth of the myth is therefore established by the overall impression of involvement which it produces in us.

However, we should not stop at romanticizing life under the pressures of mythical beliefs nor should we, as philosophers of the 21 st century romanticize nature, which can be exceedingly sensitive and harsh. Now the challenging questions arise how can the unquestioning attitude found in the Igbo man's mythic beliefs help him in conquering nature which, he has not fully discovered? This fear which prevents the Igbo mythic man from investigating nature has to some large, extent drew him back

Copyright () International Association of African Researchers and Reviewers, 2006-2017: www.afrevjo.net.

Indexed African Journals Online: www.ajol.info 
into mental indolence, underdevelopment and technological backwardness. How can the mythic man in African (who is besieged and influenced directly or indirectly by scientific and technological innovations) turn a blind eye to happenings around him while the rest of the world intimidate, oppress him into perpetual dependency? These same questions stared Kenneth Kaunda in the face hence, he asks "Is there any way that my people can have the blessings of technology without being eaten away by materialism and the spiritual dimension of life?" (24).

This concern becomes more disturbing on the discovery that modern cultures, which have been demythologized produce in the uneducated and unsophisticated masses, mythical subcultures of sects, astrology, black magic and even the cult of film stars and pop idols. Even the attempt at demythologizing the bible by Rudolf Bultman, tends to lead to another religion for theologians and some rationalists but without any impact on the broad masses.

It is consequent upon the foregoing that, this paper proposes an integrative method which welcomes both scientific and the positive social control enhancing values of mythic cultures. Such integrated sciento-mythical ideology will not only respect the morally enriching myths elements in African culture but will as well make a way for healthy sciento-technological orientation that will be protective of the human person and his cultural values. The combination of the relevant aspects of myth with the techno-scientific knowhow will result in a better-balanced perspective or worldview that propels social development security and social cohesion through an enhanced social control system which is enabled by an early moral orientation, which in turn rubs off positively on the society.

\section{Conclusion}

Myths as an effective logic for social control has to a large extent been discussed in this paper using the instantiation of Igbo people of Nigeria. We were able to consider myths as a contextual logic and attempted not only to identify the Igbos and the significances of some of their myths. Rather, we went further to explore how Igbo myths help in the socio-cultural orientation of their young towards social control, which eases off, the gargantuan challenges associated with failed social control systems. We found out that myths appeal to the supernatural, resist revisions, modification and are rigid and fixed hence, uncritical but based on different logic that typifies faith or even poetry. Besides, such uncritical ideology, when solely adopted in the face of twentyfirst century sciento-technological scholarship and worldview may at best, retard a society. Consequently, we suggested an integrated sciento-mythical ideology bearing in mind that, living myths are embedded in cultures. Our suggested fusion, when adopted as a pragmatic approach to living, will engender both sciento-technological growth and give cultural values the much-needed recognition and without much abuses of human personhood and cultural and epistemic values of indigenous societies.

\section{Works Cited}

Alston, Reginald J., Harley, Debra, and Lenhoff, Karen "Hirchi's Social Control Theory: A Sociological Perspective on Drug Abuse Among Persons with Disabilities". The Journal of Rehabilitation. 1995. Web 15 Feb. 2017 
"A family Strengths Model of Adjustment for African American Clients with Disabilities". Journal of Counseling and Development, 74, 378-383. Print.

Anyanwu, Herbert, O. Knowing the Way and the What: Anthology of Ideological Myths, Lagos: Minder International Publishers. 2002. Print.

Bouchard, Yves, "Contextual Logic and Epistemic Contexts". http//wwwcontextuallogic Web. 27 January, 2017.

Boundless "Social Control” http//www.Sociology Boundless, Web 15 Feb. 2017

Brandom, R. ed. Empiricism and the Philosophy of Mind with an Introduction by Richard Rorty and a Study Guide by Robert Brandom. Cambridge, M.A: Harvard Up, 1997. Print.

Caird, Edward. Britannica: Internet Guide Selection. www.phipages.com.27 Jan.2017.

Camus, Albert. "The Myth of Sisyphus". The Meaning of Life. ed. E.D. Klem Ke, Oxford: Oxford Up, 1981. Print.

Chriss, J.J. "The Function of the Social bond", Sociology and Criminology publications 2007, 25. http://engagedsholarship.csuohio.edu.c/soc-cum-facpuls/25

Detienne, Marcel. The Creation of Mythology. Trns. Margaret Look. Chicago: Chicago Press, 1986. Print.

De Vries, W. and Triplett, T. Knowledge, Mind and the Given: A Reader of Sellars' Empiricism and the Philosophy of Mind. Indianapolis, I.N.: Hackett, 2000. Print.

Durkheim, Emele, The Rules of Sociological Method. Ed. G. E. G. Catlin Chicago: Chicago press 1950. Print.

Edwards Paul. Editor, Encyclopedia of Philosophy, Volume 12. London: Gale/Thomson Learning 2008 Edition. Print.

Emecheta, Oji. African Traditional Religion. Umuahia: Trinity College Publication, 1998. Print.

Getier, Edward. Is Justified True Belief Knowledge? Oxford: Oxford Up, 2003. Print.

Gusdor G. "La Philosophie des Valeurs" Eds Sciacca, M. F. Les Grands Courants de la Pensee Contemporarie, Part II; Vol. 1. 2002. Print.

Hirschi, Travis. The Causes of Delinquency. Berkley: California Up, 1969. Print.

"Causes and Prevention of Juvenile Delinquency". Sociological Inquiry. 47, 322-341. Print.

Ihejirika, Cardinal. "Myth as a source of Knowledge in Igbo Worldview", Port Harcourt: University of Port Harcourt, Unpublished Master's Degree Thesis, 2005. Print.

Isaac, James and Smith, Jane. "Review" What is Mythology? Channing L. Bete Co. Inc. 2006 Web.www.di.ket.org 2/12/2016.

Kagame, A. "La Sacre Payen, Le Sacre Chreton". Aspects Delaculture noire Cahier, 1624 Recherches et D'ebates, Paris: Presence Africaire, 1958. Print.

Copyright () International Association of African Researchers and Reviewers, 2006-2017: www.afrrevjo.net.

Indexed African Journals Online: www.ajol.info 
Kaunda, Kenneth, A Humanist in Africa, Nashville: 1966. Print.

Levi-Strauss, Claude, Anthropologie Structure. Paris: Plon, 1958. Print.

Lincoln, Bruce. Concezione del tempo edimesione politica de mito, SMSR 9:7-86, 2017. Print

Lundberg, G. A., Foundations of Sociology, New York: Macmillan, 1939. Print

Malinowski, B. Myth in Primitive Psychology. New York: Norton and Co. 1926. Print.

Mc Carthy, John and Sas Buva C. "Formalizing Context (expanded notes)" ed.s. Atocha Aliseda, Robvan Glabbeek, and Dag Westerstahl, Computing Natural Language, Stanford: CSLI Publications, 1994. Print.

Meaning of life - Nihillism. "Summary of Albert Camus The Myth of Sisyphus" Nov. 22, 2015. Web 15 Feb. 2017.

O'Connor D. J. A Critical History of Western Philosophy, London: West Minster press, 1979. Print

Plato, The Republic. Ed. Rouse, W. H. D., Penguine Group Inc. Print.

Ruch, E. A., Anyanwu, K.C., African Philosophy, an Introduction to the Main Philosophical Trends in Contemporary Africa, Rome: Catholic Booth Agency, 1984. Print.

Sellars, Wilfred. "Empiricism and the Philosophy of Mind". Minnesota Studies in the Philosophy of Science Vol. 1. Eds. H. Feigl and M. Scriven Minneapolis, M. N: University of Minnesota Press. Print.

Synnove des Bouvrie, "The Definition of Myth: Symbolic Phenomena in Ancient Culture". Papers from the First International Symposium on Symbolism, Tromso: University of Tromso, June 4, 19... print.

Shmoop Editorial Team, "Sisyphus Summary", in www.Shmoop:Shmoop University, Inc. 11 Nov. 2008. Web. 14 Feb. 2017

Turnbull, Nick. "African Traditional Wisdom, Magic and Medicine". Truth, Knowledge and Society, Eds. Asiegbu, M. and Chukwuokolo, C.J., Abakiliki, Pacts G.M. Press, 2012. Print.

Uduigwomen, A. Footmarks on African Philosophy. Lagos: Ogbinaka and Obaroh Publishers, 1995. Print. 